\title{
How to improve the functionality, nutritional value and health properties of fermented milks added of fruits bioactive compounds: a review
}

\author{
Amanda Alves PRESTES ${ }^{1}$, Maryella Osório VARGAS², Cristiane Vieira HELM ${ }^{3}$, Erick Almeida ESMERINO ${ }^{4}$, \\ Ramon SILVA ${ }^{4}$, Elane Schwinden PRUDENCIO ${ }^{1,2 *}$ (D)
}

\begin{abstract}
Fermented milks, with diverse manufacturing, fermentations and specific strains, have been consumed around the world, with a millennial knowledge of their production. These dairy products have a potential nutritional value, taking food industries to invest, nowadays, in dairy products with a functional and healthy appeal due to the changes in the habits and diet of the population. The addition of natural ingredients from vegetables and fruits into fermented milks is a tendency nowadays. The inclusion of natural additives may change the texture, composition, sensory attributes and increase of the shelf life since some compounds are related to have a high antioxidant activity, which decreases the development of deteriorating microorganisms. These called bioactive compounds are synthesized by plants and also may contribute to the fermented milk formulation, in special from fruits, which increase the sensory acceptance. Several classes of fruits bioactive compounds are associated to several health benefits and are a base of many studies about functional fermented milks, reported in this review. This theory background becomes essential for future studies and dairy products development.
\end{abstract}

Keywords: dairy products; functional food; natural additives; antioxidant activity; prebiotics.

Practical Application: Potential functional properties of fermented milks added of fruit bioactive compounds.

\section{Introduction}

The dairy products manufacturing is known since antiquity, with the fermentation process as a traditional approach to food preservation. Nowadays, dairy products are substantial in most dairying countries where produce, in large demand, fermented products including butter, cheeses and fermented milks (Surono \& Hosono, 2011). Due their nutritional value and taste, fermented milks are considered a product with high potential for the development of new dairy products, being explored by dairy industries (El Hatmi et al., 2018).

Fermented milks, with an old knowledge and appreciation around the world, have an acidic property due to the specific microorganism's development. The low $\mathrm{pH}$ of the product prolongs the shelf-life of the milk and the fermentative process generates physicochemical and organoleptic changes due to synthesized metabolites by inoculated strains, contributing to sensory characteristics pleasant to the taste. Beyond sensory attributes, fermented milks, mainly yogurts, are very appreciated by consumers due to practicality and better digestibility compared to the milk. This dairy matrix contains all the necessary components to cell growth, becoming an ideal vehicle for the development of a probiotic product with a functional appeal (Granato et al., 2018; Verruck et al., 2019).
Foods with a functional appeal are those that, besides to promote basic nutrients, when consumed in a routine, produce benefic effects on the organism (da Costa, 2017). The search for healthy food, with nutritive functions and health benefits, is quite common nowadays, once a bad diet induces an increase of cardiac diseases, diabetes, and obesity. Changes in the diet are increasingly present in everyday life and food industries invest in the development of products with functional appeal. In these products, there is a tendency to add natural ingredients in the formulation, including those that are in the fruits and vegetables composition; the bioactive compounds (Domínguez Díaz et al., 2020; Fazilah et al., 2018; Yassin et al., 2018).

Bioactive compounds are synthesized by vegetables, including leaves, fruits, seeds, or roots which promote health benefits when consumed regularly. The consumption of these natural compounds is related to a decrease in the incidence of noncommunicable diseases, diabetes, cardiovascular diseases, and the reduction of carcinogenic cells (Cutrim \& Cortez, 2018; Yassin et al., 2018). Among the bioactive metabolized by plants, there are unsaturated and polyunsaturated fatty acids, several classes of polyphenols, carotenoids, vitamins, phytosterols, and dietary fibers (SeptembreMalaterre et al., 2018). Emerging studies about adding bioactive compounds from fruits, juices or extracts in dairy matrices have interesting and promising results, once that milk is a good vehicle 
for the incorporation of these natural compounds and may decrease the use of synthetic additives (de Carvalho et al., 2019; Granato et al., 2018; Jaimez-Ordaz et al., 2019). In fermented milks, the addition of fruit bioactive compounds is a potential to enrich the dairy product structure, besides being very accepted by consumers (Balthazar et al., 2019; Casarotti et al., 2018; Fidelis et al., 2020; Jaimez-Ordaz et al., 2019).

Taking into consideration that the use of fruit bioactive compounds as an additive is an emerging area in studies and dairy industries, this review aims to show the main classes of bioactive compounds presents in fruits and also their influence in fermented milk properties, once that this is an essential theory to study and develop a new dairy product with a functional appeal.

\section{Types of fermented milks}

The fermented milk is formed by the ability of specific lactic acid bacteria (LAB) to hydrolyze lactose molecules in a fermentation process, synthesizing lactic acid to the surrounding and reducing the milk $\mathrm{pH}$ with or not coagulation. This acidity from lactic acid is responsible to form gel-like products by the casein precipitation due to reach the isoelectric point at $\mathrm{pH} 4.6$ (Surono \& Hosono, 2011). With the acidic surrounding, specifics LAB can inhibit the development of spoilage microorganisms, increasing the product shelf-life for several days. The starter culture must be viable, active, with a high count in the product and, if the fermented milk is submitted to a heat treatment at the end of the process, the requirement for the viability of the cells is not applied (Food and Agriculture Organization of the United Nations, 2003). According to this Codex Alimentarius, the dairy matrix may be enriched with powdered milk, flavorings, sweeteners, thickeners, and/or fruits pulp to obtain consistency and desirable flavor in the final product. Fermented milks comprise a diversity of products and all of them must meet all the prerequisites of standard and quality to guarantee a safe consumption.

Around the world, fermented milks are manufactured using dairy matrix from diverse species according to environmental characteristics to raise a flock. In some European and Asian countries, it is common to produce this dairy product from buffalo, donkey and mare's milk, while in African countries is also common to consume fermented milk from camel's milk(Aspri et al., 2018; El Hatmi et al., 2018; Miao et al., 2020; Rasika et al., 2020). These dairy products are also produced from small animal milks, as sheep and goats; however, the yield is lower than those dairy products from large mammals (Balthazar et al., 2019; Ranadheera et al., 2018; Verruck et al., 2019).

The most consumed fermented milk is the yogurt, which contains several textures, fat contents, and flavors. With an old Turkish origin, the word yogurt is derived from a Turkish verb (jogurt), which means "coagulated or curdled". Traditionally, the product is obtained by lactic fermentation, with a controlled inoculum or in a spontaneous and primitive process, since in the natural milk microbiota there are specific strains that synthesize lactic acid in metabolic pathways. However, this process is slower due to competition from other microorganisms for the same substrate (Pimentel et al., 2017; Surono \& Hosono, 2011). Symbiotic thermophilic cultures of Streptococcus salivarius subsp. thermophilus and Lactobacillus delbrueckii subsp. bulgaricus (without a name modification according to the new reclassification of the Lactobacillus genera in the Microbiology Society by Zheng et al. (2020) are normally used in yogurts manufacture. These strains may be also in symbiosis with other acid-lactic bacteria which can contribute to the particularity of the final product. Approximately 2 to $5 \%$ thermophilic culture is added, and the milk is incubated at $42-45^{\circ} \mathrm{C}$ for $3-6$ hours until the total acidity reaches $0.9-1.2 \%$ and $\mathrm{pH} 4.4$, characterizing the product with a smooth aspect, viscous gel and acidic flavor (Pimentel et al., 2017; Surono \& Hosono, 2011). Yogurts are commercialized by the traditional method, which the fermentation occurs inside packing (Figure 1) or bottle after the fermentation incubated in tanks, classified as stirred (Figure 2). These products also may be produced as a drinking type, which is similar to stirred type, however, the coagulum is broken down to a liquid form before being packed (Figure 3).

The acidophilus milk is manufactured with yogurt-like features, adding starter culture until the product reaches a maximum acidity of 1.5 to $2 \%$, however, the fermentation must be made exclusively by Lactobacillus acidophilus strains (this species also without a name modification according to Zheng et al. (2020)). The cells development occurs slowly into the milk and it is indispensable to keep the inoculum activity with daily addition of starter culture. With milk coagulation in 18 to $24 \mathrm{~h}$, the product is cooled and homogenized to pack and stored at $4{ }^{\circ} \mathrm{C}$ (Surono \& Hosono, 2011).

Kefir, with an alcoholic and acidity characteristic, is a fermented milk in which the process occurs from kefir granules, composed by polysaccharides associated with bacteria and yeasts that are an initial culture to lactic fermentation. The process may

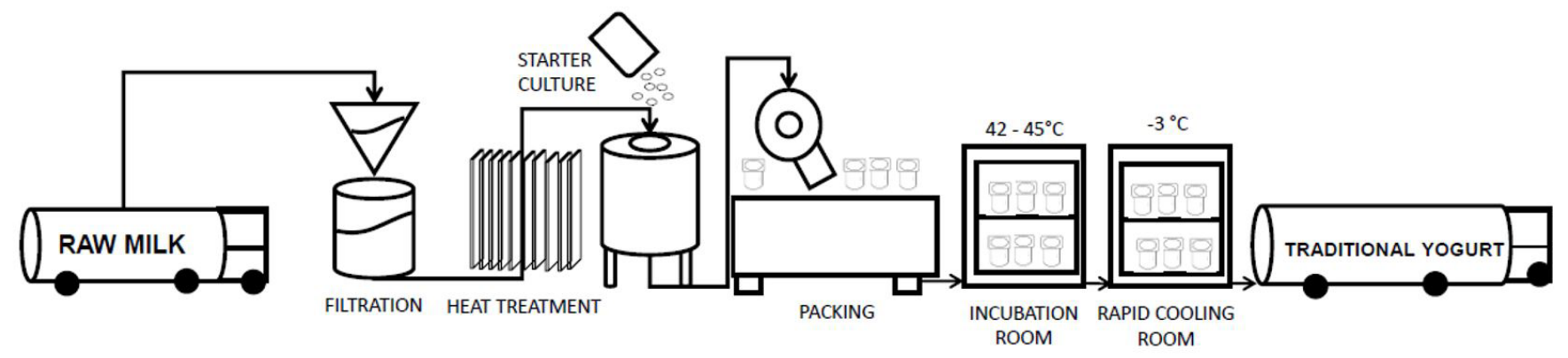

Figure 1. Traditional yogurt process. 


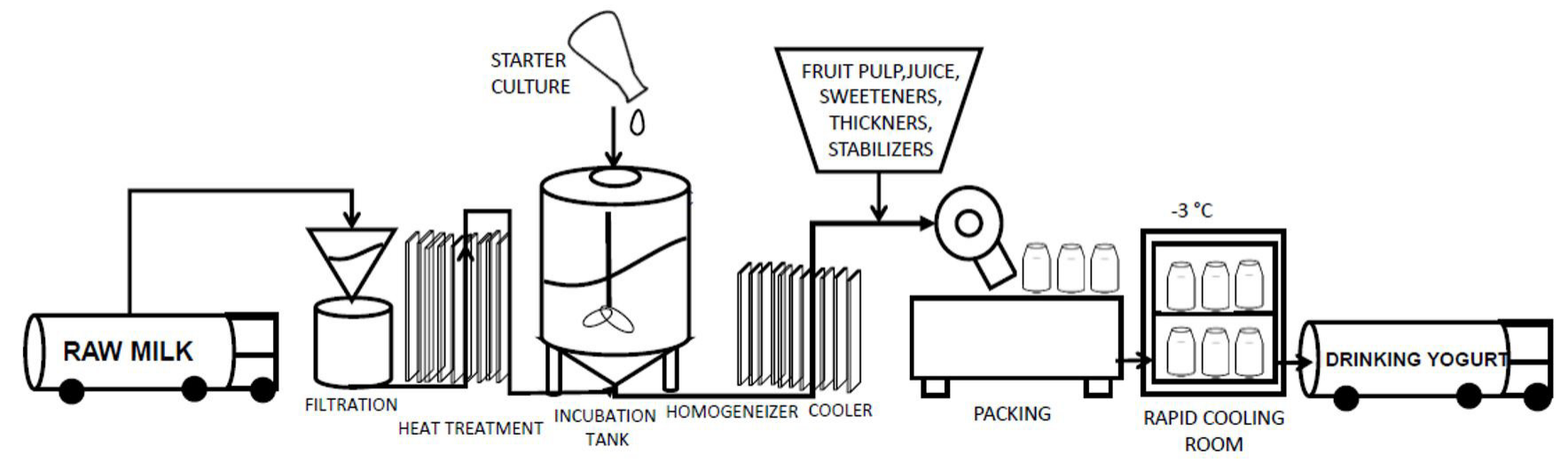

Figure 2. Stirred yogurt process.

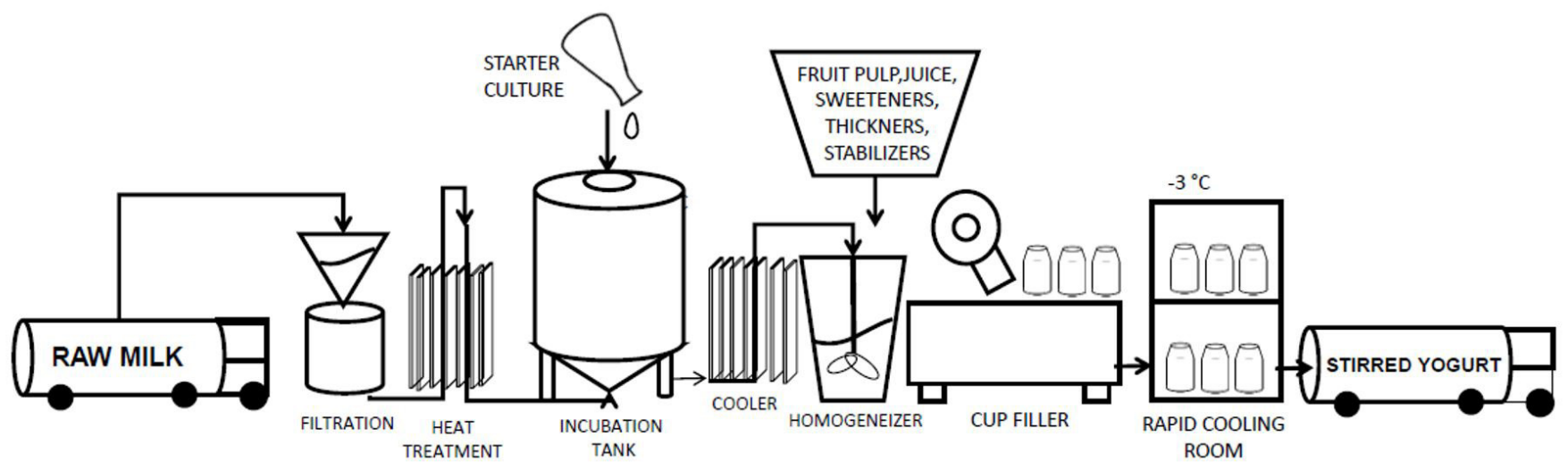

Figure 3. Drinking yogurt process.

result in a little gas formation, acidic flavor, creamy texture, and a mild aroma of fresh yeast, with low alcohol content among $0.08-2 \%$ and $0.9-1.1 \%$ of lactic acid (Fiorda et al., 2017). In this product, the fermentative process comes from the metabolism of Lentilactobacillus kefiri (basonym Lactobacillus kefir, according to the recent reclassification, who regrouped 26 species of Lactobacillus in new genera according to specific genes and phenotypic characteristics) (Zheng et al., 2020), Lactobacillus casei (without reclassified name), Bifidobacterium spp., Streptococcus thermophilus, some species from Leuconostoc, Lactococcus and Acetobacter genera, and the yeast Kluyveromyces marxianus. This one produces lactic acid, ethanol, and carbon dioxide. Some yeasts do not hydrolyze lactose (Saccharomyces omnisporus, Saccharomyces cerevisiae, and Saccharomyces exiguous), however, these strains synthesize ethanol and carbon dioxide from glucose molecules, which are previously released from LAB enzymatic hydrolysis (Pranav \& Nagendra, 2017; Fiorda et al., 2017; Surono \& Hosono, 2011).

The Kumys (koumiss or kumiss) is another type of fermented milk with lactic acid and alcohol content in this composition. With a liquid aspect, there is effervescence, greyish-white color, and shows an acidic and alcoholic taste. Traditionally, it is manufactured from mare's milk, however, in East Asian countries, the matrix of this dairy product is the camel's milk (Akuzawa et al., 2011). The fermentation occurs by Lactobacillus delbrüeckii subsp. bulgaricus, Saccharomyces lactis, and Kluyverromyces marxianus with carbon dioxide metabolized by cells which confers gasification for the product, contributing to the final taste. The traditional kumys manufacturing is performed with raw equine's milk, quite common in Central Asian. The fermentation for 3 to 8 hours occurs inside of a leather sack, (denominated "turdusk") and the inoculum added is a part of the milk with a mixture of bacteria and yeasts of a pre-fermentation from previous days. The nontraditional manufacture is performed with standard protocols and it is important to expand the marketing and consumption of equine's milk to other countries. In the pasteurized mare's milk, pure cultures of Lactobacillus bulgaricus are used for kumys manufacturing and yeasts as Saccharomyces lactis are the best for alcoholic fermentation. The acidity ranges from $0.6-1.2 \%$ and alcoholic content from $0.7-2.5 \%$, classifying this product, according to lactic acid and ethanol content, in three categories: mild, medium, and strong (Pranav \& Nagendra, 2017).

Another fermented milk appreciated in North America and Europe is the buttermilk, with its definition very flexible depending on the country. It may be associated with sour milk, cultured buttermilk, cultured skim milk or cultured milk. The buttermilk is the aqueous phase released in the manufacture of butter and, in the traditional fermentative type, may be produced by churning a cream with relatively low-fat content for the mesophilic fermentation. It also may be used skim milk for lactic acid fermentation; however, the appropriate denomination for this product is cultured or fermented buttermilk. The acidity must be not less than 
$0.60 \%$ in lactic acid, even though this product composition changes according to the butter-making technology and the season of the year. The fermentative process occurs with an addition of mesophilic cultures as Lactococcus lactis subsp. cremoris, Lactococcus lactis subsp. diacetylactis, Leuconostoc mesenteroides and its subspecies (Chandan, 2007; Surono \& Hosono, 2011).

In all fermented milks, the manufacture is performed with the use of desirable LAB. Several bacteria and yeasts genera are classified as probiotic, contributing to the functional and economic value of a probiotic dairy product. Probiotics are living microorganisms that confer innumerable health benefits to host's health when are regularly administrated in suitable amounts, must belong to the intestinal microbiota from humans or warm-blooded animals (Hill et al., 2014). Among the health benefits are included regularity of gut microbiota, protection against pathogens in intestinal cells, anti-carcinogenic properties, antimicrobial and antidiabetic potential and improvements to the digestive process (Ranadheera et al., 2018; Rasika et al., 2020; Shafi et al., 2019). Recent studies also highlight specific probiotic strains in potential protective effects on bones and in the treatment of osteoporosis (Lee et al., 2020). Species of Lactobacillus and Bifidobacterium genera are usually added in dairy products to confer probiotic effects since they are studied in the entire human gastrointestinal tract (Balthazar et al., 2019; Casarotti et al., 2018; Pena et al., 2021; Rasika et al., 2020; Shafi et al., 2019). However, the probiotic effectiveness depends on the viable cells count per gram of food, in the moment of consumption. Only is a probiotic food if the count is at least $10^{6} \mathrm{CFU}$ (Colony-Forming Units) per gram, with a recommended daily dose of $10^{8}$ to $10^{9} \mathrm{CFU} . \mathrm{g}^{-1}$ (Boylston et al., 2004).

Dairy products contain a range of nutrients that are essential to microorganism's development, becoming the most vehicles for probiotic cells addition, in special to fermented milks. In addition to nutritional properties, dairy products may contribute to probiotic survival through the gastrointestinal due to the buffer effect and the fat globules, which protect the benefic bacteria against the stomach acid (Balthazar et al., 2019; Casarotti et al., 2018; Verruck et al., 2020). The versatility of fermented milks and their high acceptance by consumers become these products a good daily source of probiotics.

\section{Fruit bioactive compounds and their influence in fermented milks}

The large consumption of a variability of foods is particularly important not only for nutritional value but also for biological activity. Fruits and vegetables synthesize chemical compounds, classified as phytochemicals, which may generate several benefits to human health (Domínguez Díaz et al., 2020; Yahia et al., 2019). These "non-nutrients" are capable to act as modulators of metabolic processes in the organism, decreasing the early incidence of degenerative diseases (Septembre-Malaterre et al., 2018).

The plant's evolutionary process made possible the synthesis of compounds related to their defense system. The biotic and abiotic stress influences the development of compounds in vegetable cells with insecticide, antifungal, and antibacterial functions. The oxidative stress originates free radicals and plants also synthesize antioxidants capable to decrease chain reactions and reactive species of oxygen (ROS) content which, in excess, are toxic to cells (Choudhary et al., 2019). Bioactive compounds may act as antioxidants in the reducing action, hydrogen donation, inhibition of singlet oxygen or incapacity of chelate metals. The synthesis of these compounds is causally related to the environment of vegetable growth since the naturally cultivated plants have higher bioactive content. Depending on each species, native fruits, for example, have higher vitamins and phenolic compounds content, being the basis of several studies due to their promising health benefits (Yahia et al., 2019). In addition to the knowledge about the beneficial action of bioactive compounds in the human body, consumers have their criteria of acceptance, once that they choose food concerning its flavor and appearance. The addition of pulps, juices, extracts, or fruits pomace in fermented milks may enrich the taste and the quality of the dairy product, improving its nutritional, physicochemical and sensory properties (Septembre-Malaterre et al., 2018).

\subsection{Fatty acids}

A regular consumption of fatty acids, mainly polyunsaturated from omega 3, 6, and 9 families are related to health benefits as the reduction of LDL cholesterol levels, anti-inflammatory action, decrease in the incidence of carcinogenic and cardiovascular diseases, arteriosclerosis and Alzheimer. Avocados, coconuts and Amazonian fruits as açaí (Euterpe oleracea), tucumã (Astrocaryum aculeatum) and buriti (Mauritia flexuosa) are examples of fruits which the composition is rich in saturated fatty acids (SFA), monounsaturated fatty acids (MUFA) and polyunsaturated fatty acids (PUFA) (Espírito Santo et al., 2010; Serra et al., 2019).

From Omega 6 family, an isomer of the linoleic acid is the conjugated linoleic acid (CLA); related to several metabolism benefits due to its regular consumption, including anti-obesity effects, a decrease of LDL cholesterol and anticancer effects. Through the hydrogenation of the polyunsaturated acid, this isomer is formed usually in the digestive tract. In the human large intestine, some probiotic genera of bacteria (Lactobacillus, Propionibacterium, Bifidobacterium and some strains of Clostridium and Leuconostoc) are capable to metabolize linoleic acid in CLA by an enzymatic process after digestion of food that contains polyunsaturated acids in their composition, as fruits with higher fat content, fermented meat, milk, and dairy products, including fermented milks (Csapó \& Varga-Visi, 2015).

Dairy products provide only $70 \%$ of the total CLA daily intake, and due to achieving the recommended dose, several technological alternatives are being used to increase the CLA content in milk and dairy products as the addition of specific cultures that metabolize this fatty acid or enrich the dairy product with CLA from seeds, fruits or extracts to improve their nutritional value. Borges et al. (2019) evaluated the effect of Leuconostoc mesenteroides and Lactococcus lactis on the fatty acids profile and on the inhibition of Listeria monocytogens in fermented cream. This pathogenic bacteria count was reduced by the development and competition of the Ln. mesenteroides and Lactococcus lactis cells, besides, the fatty acids profile was 
changed with a decrease of MUFA and PUFA, as well as an increase of SFA and $60 \%$ of CLA, highlighting the potential of this functional property. The addition of açai pulp in yogurts was performed by Espírito Santo et al. (2010), who evaluated the effects of the fruit in probiotic bacteria development (Lactobacillus acidophilus, Bifidobacterium animalis ssp. lactis BI04 and Bifidobacterium longum BI05) and in the fatty acid profile (Table 1). The açaí pulp addition increased the probiotic cells count and monounsaturated and polyunsaturated fatty acids contents. Besides, this fruit improves the production of $\alpha$-linoleic and its conjugated linoleic acid during the fermentation of the dairy product.

\subsection{Phenolic compounds}

Phenolic compounds are secondary metabolites synthesized by plants with a defense mechanism against insects, pathogenic microorganisms, ultraviolet radiation (UV), and are also related to fruit pigmentation. These compounds are responsible for astringent flavor, aroma, and oxidative stability of vegetables and fruits. According to the chemical structure, phenolic compounds show innumerable constituents, and all these compounds exhibit hydroxyls $(\mathrm{OH})$ in molecules, which confer antioxidant activities. With one or more aromatic ring linked to at least one hydroxyl radical, phenolic compounds are classified according to the number of phenolic rings and their chemical structures, with the main groups: phenolic acids, flavonoids and non-flavonoids (Li et al., 2014). In the daily diet, vegetables and fruits are the main sources of phenolic compounds such as flavonoids, phenolic acids, stilbenes, and lignans. Several studies are related to the influence of regular consumption of fruits phenolic compounds with health benefits, as the reduction in the incidence of noncommunicable diseases, diabetes, and cancer (Alenisan et al., 2017; Fidelis et al., 2020; Yassin et al., 2018). According to the fruit's composition, phenolic classes or subclasses are abundant in specific species as grapes, apples, cherries, oranges, berries and pomegranates (Casarotti et al., 2018; Gullon et al., 2016; Pantelić et al., 2016; Zielinski et al., 2019). Nowadays, several studies about native Brazilian fruits are on the rise according to their composition rich in phenolic compounds, highlighting fruits from Myrtaceae family as the camu-camu (Myrciaria dubia), guava (Psidium guajava) araçá (Psidium cattleianum) and guabiroba (Campomanesia xanthocarpa O. Berg) (Fidelis et al., 2020; Silva-Rodrigues et al., 2020). Considered a functional food, the guabiroba fruit contains around $131.90 \mathrm{mg} 100 \mathrm{~g}^{-1}$ of phenolic compounds, besides, this fruit has a sweet and fresh pup with a potential application in future food formulations (SilvaRodrigues et al., 2020).

When phenolic compounds from fruits, pulps, juices, pomace, or extracts are added in dairy products, changes in physicochemical, sensory, and microbiological properties are possible. In studies about the addition of juice and grape peel flour into yogurts (Karnopp et al., 2017) measured changes in phenolic content, antioxidant activity, sensory, textural and physicochemical properties of these dairy products (Table 1). The grape juice increased the phenolic content, antioxidant activity, and viscosity of yogurts while the grape peel flour increased the total fiber and ash content, hardness, and consistency. The grape peel contains fibers that act as stabilizers and change the yogurt texture and, besides, to give functional and textures properties to the yogurt, the use of fruits peel or pomace can contribute to the reduction of resides and add value to a fruit by-product.

In a research about the functional characterization of a yogurt with sheep's milk added of strawberry juice, inulin, and potato starch, (Balthazar et al., 2019) measured the viability of a probiotic strain added to the formulation (L. plantarum) in in vitro simulated gastrointestinal conditions (Table 1). After the simulated digestion, cells showed high viability. Fruit juices, inulin and the potato starch have a prebiotic activity, influencing positively in the development of the probiotic cell. The strawberry juice increased the phenolic compounds and antioxidant activity of the fermented milk; besides, flavonoids and phenolic acids can inhibit the lipid oxidation, which is responsible for chemical compounds that form off-flavors. This antioxidant activity is related to electrons donation to neutralize the chain reaction by free radicals and may prolong the yogurt shelf-life. Also, the low $\mathrm{pH}$ (4.6) becomes fermented milks good carriers of phenolic compounds due to their interaction is maximum in an acid surrounding.

Phenolic compounds can also contribute to the color of fruits, which is the most important parameter in foods to influence the consumer's choice, and, nowadays, people prefer to consume colorful food with natural colorants from vegetables, roots, and fruits. Into the flavonoids class, anthocyanins are responsible for the pigmentation of fruits, ranging from red to dark blue and are included in grapes, berries, apple peels, and plums composition. The more intense the color is, the higher the anthocyanins content and this red/purple color can be added into the fermented milk formulation, improving the visual acceptance of the product. Betacyaninins included in the betalain class, from anthocyanin's group, were studied as a natural colorant in yogurts added of red pitaya pulp (Table 1) (Gengatharan et al., 2016). Compared to a commercial colorant, the natural colorant from the red pitaya showed more stability during the storage. Into the anthocyanin's composition from this fruit, there are phyllocactin and hylocerenin, which are more resistant pigments. Besides, yogurt with red pitaya pulp showed higher antioxidant activity and lower syneresis due to the ability of some phenolic compounds, as the vanillin, to stabilize milk peptides protein by hydrogen bonding and electrostatic interaction. These betalains also increased the viability of Streptococcus thermophilus and Lactobacillus bulgaricus, the traditional thermophilic culture. In a research about kefir enhanced with mango peel, probiotic strains also have an increase in the viability and count. In this work, the fermented milk showed higher phenolic compounds content and antioxidant activity, when compared to a control sample (Table 1). During the fermentation, probiotic cells can synthesize enzymes that release phenolic compounds in the matrix (Vicenssuto \& de Castro, 2020). Therefore, phenolic compounds in the fruit's peels, pulps, or seeds can have a positive effect on the antioxidant properties of fermented milk.

\subsection{Carotenoids}

Carotenoids comprise the biggest group of pigmented compounds in nature, with approximately 600 isolated and 
Table 1. Studies about fruits bioactive compounds in fermented milks.

\begin{tabular}{|c|c|c|c|c|c|}
\hline Fermented Milk & Country & Fruit & Bioactive compound & Conclusion & Author \\
\hline Probiotic Yogurt & Brazil & $\begin{array}{c}\text { Açaí pulp (Euterpe } \\
\text { oleracea) }\end{array}$ & $\begin{array}{c}\text { Fatty acids (mainly } \\
\text { oleic and palmitic acid) }\end{array}$ & $\begin{array}{l}\text { The açaí pulp increased the CLA } \\
\text { formation and improved the } \\
\text { development of the probiotic cell. }\end{array}$ & $\begin{array}{c}\text { (Espírito } \\
\text { Santo et al., 2010) }\end{array}$ \\
\hline Organic yogurt & Brazil & $\begin{array}{l}\text { Grape juice }(\mathrm{GJ}) \\
\text { and grape peel } \\
\text { flour (GPF) }\end{array}$ & $\begin{array}{l}\text { Phenolic compounds } \\
\text { and soluble fibers }\end{array}$ & $\begin{array}{l}\text { GJ increased phenolic content and } \\
\text { antioxidant activity. GPF increased } \\
\text { ash, fibers, and texture properties. } \\
79 \% \text { of sensory acceptance. }\end{array}$ & (Karnopp et al., 2017) \\
\hline $\begin{array}{l}\text { Probiotic sheep's milk } \\
\text { yogurt }\end{array}$ & Brazil & Strawberry juice & $\begin{array}{l}\text { Phenolic compounds } \\
\text { and prebiotic fibers }\end{array}$ & $\begin{array}{c}\text { Increase of phenolic content and } \\
\text { improvement of probiotic cells } \\
\text { viability }\end{array}$ & (Balthazar et al., 2019) \\
\hline Yogurt & Malaysia & Red pitaya & $\begin{array}{l}\text { Betacyanin (from } \\
\text { anthocyanins group of } \\
\text { phenolic compounds) }\end{array}$ & $\begin{array}{l}\text { The higher stability of betalains } \\
\text { from red pitaya pulp during the } \\
\text { storage. Decrease of the syneresis and } \\
\text { improvement of thermophilic culture } \\
\text { development. }\end{array}$ & (Gengatharan et al., 2016) \\
\hline Yogurt & Brazil & Goji berry & $\begin{array}{l}\text { Carotenoid } \\
\text { (Zeaxanthin) }\end{array}$ & $\begin{array}{l}\text { Incorporated into nanoparticles } \\
\text { before adding in the yogurt, this } \\
\text { technique enhances the carotenoid } \\
\text { retention at the end of the storage and } \\
\text { had a protecting effect in an in vitro } \\
\text { gastrointestinal process. }\end{array}$ & (de Campo et al., 2019) \\
\hline Yogurt & Brazil & Cantaloupe melon & $\begin{array}{l}\text { Carotenoid ( } \beta \text { - } \\
\quad \text { carotene })\end{array}$ & $\begin{array}{l}\text { The encapsulation of carotenoid } \\
\text { extract was added into yogurt } \\
\text { formulation, providing a yellow color } \\
\text { stabilized during } 60 \text { days of storage } \\
\text { and being a potential substitute for } \\
\text { synthetic colorants. }\end{array}$ & (Medeiros et al., 2019) \\
\hline Kefir & Brazil & Mango peel & Phenolic compounds & $\begin{array}{l}\text { Higher phenolic compounds } \\
\text { content and antioxidant activity } \\
\text { when compared to a control sample. } \\
\text { Phenolic compounds improved } \\
\text { the probiotic development, with a } \\
\text { potential prebiotic action. }\end{array}$ & $\begin{array}{c}\text { (Vicenssuto \& de Castro, } \\
\text { 2020) }\end{array}$ \\
\hline Probiotic yogurt & Iran & Date extract & $\begin{array}{l}\text { Phenolic compounds, } \\
\text { dietary fibers }\end{array}$ & $\begin{array}{l}\text { The date extract had a high influence } \\
\text { on probiotic development, an increase } \\
\text { of the total soluble solids, and } \\
\text { antioxidant activity. The fermented } \\
\text { milk was sensorially accepted. }\end{array}$ & (Abdollahzadeh et al., 2018) \\
\hline Probiotic yogurt & Italy & Passion fruit & Dietary fiber & $\begin{array}{l}\text { The addition of fibers increases the } \\
\text { viscosity and firmness of the yogurts, } \\
\text { which were sensorially accepted. }\end{array}$ & $\begin{array}{c}\text { (Espírito- } \\
\text { Santo et al., 2013) }\end{array}$ \\
\hline $\begin{array}{l}\text { Probiotic goat's milk } \\
\text { yogurt }\end{array}$ & Brazil & $\begin{array}{l}\text { Guava, orange and } \\
\text { passion fruit }\end{array}$ & $\begin{array}{l}\text { Dietary fiber, phenolic } \\
\text { compounds, and } \\
\text { carotenoids }\end{array}$ & $\begin{array}{c}\text { Increase of phenolic compounds, } \\
\beta \text {-carotene, and lycopene. Increase } \\
\text { in the survival rate of probiotic cells. } \\
\text { Fibers with a prebiotic effect. }\end{array}$ & (Casarotti et al., 2018) \\
\hline Yogurt & Brazil & $\begin{array}{c}\text { Camu-camu } \\
\text { (Myrciaria dúbia) }\end{array}$ & $\begin{array}{l}\text { Phenolic compounds, } \\
\text { ascorbic acid (vitamin } \\
\text { C) }\end{array}$ & $\begin{array}{l}\text { Increase of antioxidant and anti- } \\
\text { proliferative activities. High sensory } \\
\text { acceptance. }\end{array}$ & (Fidelis et al., 2020) \\
\hline Stirred-type yogurt & Canada & Apple pomace & $\begin{array}{l}\text { Phenolic compounds, } \\
\text { soluble and not soluble } \\
\text { fibers }\end{array}$ & $\begin{array}{l}\text { The fibers increase the color, total } \\
\text { phenolic content, viscosity and } \\
\text { decrease the syneresis, which is typical } \\
\text { in a stirred yogurt }\end{array}$ & (Wang et al., 2020) \\
\hline $\begin{array}{l}\text { Probiotic Fermented } \\
\text { milk }\end{array}$ & Brazil & Pomegranate juice & Phenolic compounds & $\begin{array}{c}\text { After an in vitro gastrointestinal } \\
\text { simulation, the polyphenol content } \\
\text { increased, as did the survival rate and } \\
\text { probiotic cell count }\end{array}$ & (Pena et al., 2021) \\
\hline
\end{tabular}


characterized structures. These compounds are natural pigments with a diversity of colors, ranging from yellow to red color in fruits, flowers, leaves, and roots. In the same way, carotenoids are included in the coloring of some birds, fishes, and crustaceans can be also synthesized by some fungus, photosynthetic bacteria, and seaweeds (Maiani et al., 2009; Rodriguez-Amaya \& Kimura, 2004.). With a hydrophobic structure, in plants, these compounds are stored in lipid membranes and, in vegetable cells, carotenoids have photoprotection activity, with a light and oxygen reactive species capture, in addition to a membrane structural and antioxidant activities ((Rodriguez-Amaya \& Kimura,2004). These compounds are related to the provitamin A, a precursor of Vitamin A (retinol) in the metabolism, however, of all the 600 characterized structures, only 50 can be Vitamin A precursors. Retinoids (pre-vitamin A) from dairy products, meats, and eggs ingestion, in contact to the provitamin A in gut cells are converted by an enzymatic activity into retinol molecules, which are absorbed in epithelial cells. The main sources of carotenoids in fruits, vegetables, and roots are those with yellow, orange or red colors which provide high $\beta$-carotene, $\alpha$-carotene, $\beta$ - kryptoxanthin, lycopene, lutein and zeaxanthin contents, which are the principal carotenoids in foods (Rodriguez-Concepcion et al., 2018). In fruits, the sources of these compounds are peach, nectarine, papaya, mango, orange, watermelon, and plum (Table 2).

The carotenoid content in fruits ranges according to the cultivar, environment, cultivation climate, and maturation. During the fruit ripening, in addition to the flavor and texture changes, there is the chlorophyll degradation and synthesis of carotenoids, increasing the content of this compound (Maiani et al., 2009; Rodriguez-Concepcion et al., 2018). Concerning health benefits, the daily inclusion of carotenoids in the diet can contribute to an increase of anti-carcinogenic and antioxidant activities, decrease in the incidence of cardiovascular diseases, and reduction in the degeneration of eyes cells, since there is a prevention of blood clots. Due to these benefits, there is an incentive for adding carotenoids in functional foods (Rodriguez-Concepcion et al., 2018).

Besides aggregating functional properties to a food formulation, the natural color of carotenoids can substitute synthetic colorings, which are allergenic for several people. In a recent study about the incorporation of zeaxanthin from goji berry in yogurts, de Campo et al. (2019) added this carotenoid inside of nanoparticles before putting in the yogurt formulation
(Table 1). In a food processing and storage, carotenoids are very susceptible to chemical degradation, related to its lipophilic nature and high sensitivity to the presence of oxygen, heat, and light. Therefore, the nanoencapsulation of zeaxanthin was interesting to provide more functional properties to yogurts, with high carotenoids retention at the end of the storage. In addition to the nanoparticles being sensorially imperceptible, this technique provided to have a protective effect on carotenoids in an in vitro gastrointestinal simulation. In a study also about carotenoid encapsulation in yogurts, Medeiros et al. (2019) extracted carotenoids from cantaloupe melon which was incorporated into a yogurt formulation through the nanoparticles (Table 1). In the extract, the total carotenoid content was $46.2 \mu \mathrm{g} \cdot \mathrm{g}^{-1}$, and according to previous studies, food matrices that contain more than $20 \mu \mathrm{g} \mathrm{g}^{-1}$ are a very important source of carotenoids, providing health benefits (Fleshman et al., 2011). With high $\beta$ - carotene content, the extract added to yogurt gave a yellow color and this property was stabilized during 60 days of storage, is a potential substitute for synthetic colorants.

\subsection{Phytosterols}

Phytosterols, also called plant sterols, are classified as steroid groups present in the plant composition and effect important functions in the vegetable metabolism. These compounds are related, mainly, to the ability to fluidize cell membranes and to increase the rigidity and reorganize the cytoskeleton (Ferguson et al., 2016). Phytosterols are nonnutritive metabolites which are chemically similar to cholesterol; however, this is a sterol from mammalian cells, while phytosterols are exclusively derived from vegetable cells (Demonty et al., 2009).

In nature, more than 200 different phytosterols have been isolated and classified, however, a limited number of these compounds are found in the human diet with sitosterol, campesterol and stigmasterol being, approximately, $98 \%$ of the total phytosterols in the diet. Vegetable oils, nuts, seeds, and fruits are the main sources of these compounds. In fruits, it is common to find in avocados, berries, apples, and olives compositions (Ferguson et al., 2016). The inclusion of phytosterols in the daily diet is related to the reduction of blood cholesterol levels and the circulating low-density lipoproteins (LDL), which in excess are an important risk factor to cardiovascular diseases. In studies, it was estimated that occidental populations consume

Table 2. Vitamins in fruits.

\begin{tabular}{|c|c|}
\hline Vitamin & Fruits \\
\hline \multirow[t]{2}{*}{ Pro-vitamin A (Carotenoids) } & $\begin{array}{l}\text { Pineapple, mango, melon, watermelon, orange, papaya, peach, nectarine, persimmon, acerola, guava (Psidium } \\
\text { guajava), camu-camu (Myrciaria dubia) and araçá (Psidium cattleianum) }\end{array}$ \\
\hline & Amazonian fruits: tucumã (Astrocaryum aculeatum) and umari (Poraqueiba sericeia Tul) \\
\hline Vitamin C (Ascorbic acid) & $\begin{array}{l}\text { Citrus spp., strawberry, pineapple, acerola, blackcurrant, kiwifruit, apple, guabiroba (Campomanesia } \\
\text { xanthocarpa), guava (Psidium guajava), camu-camu (Myrciaria dubia) and araçá (Psidium cattleianum) }\end{array}$ \\
\hline Vitamin E (Tocopherol) & Avocado, melon, papaya, persimmon, mango, kiwifruit \\
\hline Complex B & $\begin{array}{l}\text { Grape (Vit. B1), Melon (Vit. B6, Vit. B9), Orange (Vit. B1, Vit. B9), banana (Vit. B6, Vit. B7, Vit. B9), avocado } \\
\text { (Vit. B1, Vit. B3, Vit. B5, Vit.B6, Vit. B7), watermelon (Vit. B1, Vit. B6), plum (Vit. B6), mango (Vit. B1, Vit. B9), } \\
\text { strawberry (Vit. B5), papaya (Vit. B7, Vit. B9), orange (Vit. B9), kiwifruit (Vit. B9) }\end{array}$ \\
\hline Vitamin K & Avocado, banana, berries, grape, melon, kiwifruit, pomegranate, plum \\
\hline
\end{tabular}

Note: (Medeiros et al., 2019; Mellidou et al., 2019; Rodriguez-Amaya \& Kimura, 2004; Silva-Rodrigues et al., 2020). 
approximately $150-450 \mathrm{mg}$ of phytosterols in their daily diet; it is $50 \%$ less than the oriental population, who have a balanced diet that includes several phytosterols sources. In some situations, the intake of nutraceuticals with phytosterols is recommended to reach the threshold daily dose of two grams (Brufau et al., 2008; Ferguson et al., 2016).

With a growing global market for functional foods, there are promising opportunities for the development of enriching foods with phytosterols alleging health benefits. With a hydrophobic characteristic, these bioactive compounds have more homogeneity when esterified with fatty acids in food manufacture as dairy products, vegetable oils, margarine, orange juices, cakes, bread, chips and mayonnaises. In fermented milks, the addition of phytosterols has been studied and used since the early 2000s. These dairy products contain fat globules in the composition, which are good phytosterol carriers, very accepted, and practical. In previous studies, the matrix food form can affect the efficiency of the cholesterol-lowering in the metabolism (Demonty et al., 2009). According to these authors, solid foods with the addition of phytosterols may be related to higher effect to decrease the LDL cholesterol (approximately 5.2\%) when compared to liquid foods, probably due to the passage through the gastrointestinal tract in a longer period. With these evidence and future studies, yogurts with a rigid and viscous aspect can be potential dairy products enriched with phytosterols when compared to liquid foods, as milk or juices. Researches with the yogurt used as a food matrix for phytosterols, provided significant results of decrease LDL cholesterol levels. With daily intakes of 1.6 - 4.0 grams of phytosterols in fermented milk, the total cholesterol lowered in a median of $11 \%$ and LDL cholesterol by $15 \%$ in individual exams (Salo \& Kuusisto, 2016). According to a protocol of consumption during some weeks, fermented milk with an addition of phytosterols can provide health benefits since the properties are included in a healthy and balanced diet.

\subsection{Dietary fibers}

Dietary fibers are compounds with a high molecular mass which include vegetable carbohydrates polymers, oligosaccharides and polysaccharides as cellulose, hemicellulose, lignin, pectin and resistant starches that may be associated with some compounds, as polyphenols, waxes, proteins or phytates (Sembries et al., 2003). During the digestion, dietary fibers are not digested by enzymatic action or absorbed in the small intestine. When there is the consumption, these compounds have some properties as the stimulation of gut colony fermentation, a decrease of intestinal constipation, reduction of total and LDL cholesterol levels, and decrease of the post-prandial blood glucose and insulin levels. Besides, the regular consumption of fibers is related to the importance of preventing obesity, heart diseases, diabetes, atherosclerosis, and gut cancer (EspíritoSanto et al., 2013; Nawirska \& Kwaśniewska, 2005).

Dietary fibers are present in most of the whole grains, roots, vegetables, and fruits, highlighting avocados, bananas, apples, guavas, passion fruits, citruses, papaya and plums. Dietary fibers are classified into two groups: during the digestion and in contact with water, the soluble fibers tend to form gels, increase the viscosity of partially digested foods in the stomach and can be fermented by the gut microbiota. On the other hand, the insoluble ones remain intact during the entire gastrointestinal tract, improving the intestinal motility(Sembries et al., 2003).

New dairy products are often developed with the addition of fibers from several sources, as different fruits and their byproducts, contributing to a new flavor and improvement of physicochemical properties. Besides, the use of peels or pomaces as ingredients may reduce the impacts of industrial waste (Casarotti et al., 2018; Wang et al., 2020). In the fermented milk manufacturing, fruits, vegetables, and by-products fibers are used as a potential stabilizer due to capacities of water binding, gelling, thickening, lipid retention, and improvement of textural properties (Wang et al., 2020). The addition of fruits fiber also can increase the volume and the production yield, and with this, it may reduce the caloric content.

Several researches evaluated the effect of fruits dietary fibers on dairy products and fermented milks quality. In a study by Espírito-Santo et al. (2013), it was manufactured probiotic yogurts enriched with passion fruit fiber, with an evaluation of the rheology, microstructure, and sensorial characteristics (Table 1). Yogurts added with the fruit fiber had an increase of viscosity, reducing the amount of whey release. The pectin included in the fiber composition has a water-holding capacity, constituted by anionic hydrocolloids which adsorb polysaccharides and interact with the casein, increasing the firmness of the product (Everett \& McLeod, 2005). These yogurts were accepted in sensory analysis and the authors confirmed that passion fruit fiber is a neutral ingredient to provide high value-added fermented milk. The same behavior was evaluated by Wang et al. (2020), who added apple pomace into stirred-type yogurt (Table 1). During 14 days of cold storage, the soluble and not soluble fiber particles increased the viscosity and reduced the syneresis, which is typical in a stirred yogurt. Through an electrostatic linking, pectin can stabilize casein aggregates, resulting in casein-pectin complexes that maintain the yogurt gel. In addition, apple is the source of phenolic compounds, which increased the total phenolic content in the stirred yogurt, becoming the apple pomace a potential natural stabilizer and a functional additive.

Prebiotic characteristics of fruit fibers are in a constant study due to their health benefits and the improvement of the dairy products' quality. In research by Casarotti et al. (2018), it was evaluated the survival rate of probiotic cells in fermented goat's milk in a gastrointestinal simulation, added with guava, orange and passion fruit pomace flour (Table 1). Among the results, the total fiber content was high, as well as for total phenolic content and antioxidant activity due to a significant fraction of flavonoids be retained in the pomace after the juice extraction. With no interference in the fermentation time, the pomace addition increases the resistance of probiotics even in extreme digestion surroundings. This protective effect can be attributed to the buffer capacity of fibers and their nutrients for the development of the cell. These effects were also confirmed by Abdollahzadeh et al. (2018), who evaluated fermented milks enriched with date extract and the influence in probiotic development of Lactobacillus acidophilus strains (Table 1). Dates are rich in sugar (glucose and fructose), fibers (cellulose and pectin) in addition to phenolic compounds that confer a 
high antioxidant activity. These properties provided high cells count until 14 days due to the prebiotic properties of dietary fibers. In the fermented milk composition also had an increase of total solid content and antioxidant activity. The dairy product, among the results, was sensorially accepted, with the date extract a potential functional additive to promote healthy qualities in probiotic dairy products.

\subsection{Vitamins}

Vitamins are organic molecules classified as micronutrients due to requiring low or traces quantity for a normal metabolism development (Septembre-Malaterre et al., 2018). These compounds, without energetic value, are not synthesized in enough amounts by the human body and are supplied from the diet, especially from vegetables and fruits. According to the species, cultivar, or ripening, there are important variations of vitamins in plants. Nowadays there are recognized thirteen vitamins with diverse biological activities, solubility, and biochemistry reaction (Domínguez Díaz et al., 2020; Mellidou et al., 2019). The polarity can be one of the factors to classify vitamins. According to the solubility in water, there are vitamin $\mathrm{C}$ (ascorbic acid) and complex $\mathrm{B}$, although vitamins $\mathrm{A}$ (retinol), D, E (tocopherol), and $\mathrm{K}$ are fat-soluble. The main fruit sources of these vitamins are included in Table 2, except vitamin B12 and D which do not occur in fruits or vegetables (Dismore et al., 2003; Rodriguez-Amaya \& Kimura, 2004). Daily consumption of diverse vitamins associated with other bioactive compounds can improve endothelial functions, anti-inflammatory and anti-carcinogenic capacities, antioxidant and antitumor activities and, also, these compounds are related to the occurrence decrease of chronic non-communicable diseases (Mellidou et al., 2019; Yahia et al., 2019).

Fermented milks can be a source of several nutrients, including vitamin $\mathrm{A}, \mathrm{B}$-complex, and compared to the milk, the fermentation can enhance the nutritional value of these dairy products. Lactic acid bacteria (LAB) improve not only the physicochemical and organoleptic properties but also the nutritional value with vitamins synthesis in their metabolism, as the vitamin B12 (Capozzi et al., 2012). The addition of fruits in fermented milk can also increase the consumption of several vitamins and makes this dairy product a complete functional food. In a recent study about a characterization of yogurt added with a South American fruit seed extract, the camucamu (Myrciaria dubia), the antioxidant and anti-proliferative activities were higher when compared to a control sample, without extract. Besides, this functional dairy product was very sensorially accepted (Table 1) (Fidelis et al., 2020). The camucamu fruit is studied by the high phenolic content and vitamin $\mathrm{C}$ (ascorbic acid) and is related to an intense antioxidant activity due to its high reducing power, protecting against decontrolled cell oxidation. High antioxidant activity was also evident in yogurts added with açaí juice (Euterpe oleracea) and strawberry preparations, relating health-promoting effects to natural classes of antioxidant compounds as phenolic compounds, vitamin $\mathrm{C}$, vitamin $\mathrm{E}$ (tocopherol) and pro-vitamin A included in the composition of the fruit (Coïsson et al., 2005).

Vitamins with antioxidant properties as retinol, ascorbic acid, and tocopherol also can stimulate the viability of probiotic cells in dairy products. In a recent study about the addition of ascorbic acid and tocopherol in fermented milks, the fermentation was faster when compared to a control sample, providing higher probiotic counts. The ascorbic acid and tocopherol, as reducing agents, promote the increase of $\mathrm{H}^{+}$and $\mathrm{K}^{+}$around the cells membrane and influence the acid lactic synthesis (Soto et al., 2019). According to the Codex Alimentarius (Food and Agriculture Organization of the United Nations, 1995), the maximum allowed concentration of tocopherol in dairy desserts, including yogurts, is $500 \mathrm{mg} . \mathrm{L}^{-1}$. However, this study showed a high activity in low concentrations of 5, 7.5, and $15 \mathrm{mg} \cdot \mathrm{L}^{-1}$. Therefore, natural sources of these bioactive compounds, as fruits and juices, also may improve the functionality and activity of dairy products.

\section{Conclusions}

Fruits bioactive compounds can contribute to the benefits of the human body when administrated regularly in the diet, even if their effects are low at the beginning of the consumption. Besides, reducing the risk of chronic diseases is not related to a unique class of bioactive compounds, but is evident and proven when there are addition and interaction of several compounds in a food formulation. In fermented milks, in special, the addition of fruits is very accepted by consumers and may improve the nutritional and functional value. Bioactive compounds are important to enrich the texture and sensory attributes of fermented milks. These compounds are also related to reducing microbial and chemical deterioration, improving the probiotic development, and the quality of these dairy products. Innumerous studies about adding fruit bioactive compounds in fermented milks are performed nowadays providing new perspectives to dairy industries, which are increasingly looking for better quality and acceptance of their products.

\section{Acknowledgements}

The authors are grateful to CAPES (Coordination of Improvement of Higher Education Personnel, Brazil) by the scholarship and to CNPq CNPq (National Council for Scientific and Technological Development, Brazil) by the financial support [CNPq 405965/2016-8].

\section{References}

Abdollahzadeh, S. M., Zahedani, M. R., Rahmdel, S., Hemmati, F., \& Mazloomi, S. M. (2018). Development of Lactobacillus acidophilus-fermented milk fortified with date extract. $L W T, 98$, 577-582. http://dx.doi.org/10.1016/j.lwt.2018.09.042.

Akuzawa, R., Miura, T., \& Surono, I. S. (2011). Fermented milks: Asian fermented milks. In J. W. Fuqway \& P. F. Fox (Eds.), Encyclopedia of dairy sciences (2nd ed., pp. 507-511). London: Elsevier. http:// dx.doi.org/10.1016/B978-0-12-374407-4.00186-2.

Alenisan, M. A., Alqattan, H. H., Tolbah, L. S., \& Shori, A. B. (2017). Antioxidant properties of dairy products fortified with natural additives: A review. Journal of the Association of Arab Universities for Basic and Applied Sciences, 24(1), 101-106. http://dx.doi.org/10.1016/j. jaubas.2017.05.001.

Aspri, M., Leni, G., Galaverna, G., \& Papademas, P. (2018). Bioactive properties of fermented donkey milk, before and after in vitro 
simulated gastrointestinal digestion. Food Chemistry, 268, 476-484. http://dx.doi.org/10.1016/j.foodchem.2018.06.119. PMid:30064786.

Balthazar, C. F., Santillo, A., Guimarães, J. T., Capozzi, V., Russo, P., Caroprese, M., Marino, R., Esmerino, E. A., Raices, R. S. L., Silva, M. C., Silva, H. L. A., Freitas, M. Q., Granato, D., Cruz, A. G., \& Albenzio, M. (2019). Novel milk-juice beverage with fermented sheep milk and strawberry (Fragaria $\times$ ananassa): nutritional and functional characterization. Journal of Dairy Science, 102(12), 10724-10736. http://dx.doi.org/10.3168/jds.2019-16909. PMid:31521367.

Borges, D. O., Matsuo, M. M., Bogsan, C. S. B., Silva, T. F., Casarotti, S. N., \& Penna, A. L. B. (2019). Leuconostoc mesenteroides subsp. mesenteroides SJRP55 reduces Listeria monocytogenes growth and impacts on fatty acids profile and conjugated linoleic acid content in fermented cream. $L W T, 107,264-271$. http://dx.doi.org/10.1016/j. lwt.2019.02.085.

Boylston, T. D., Vinderola, C. G., Ghoddusi, H. B., \& Reinheimer, J. A. (2004). Incorporation of bifidobacteria into cheeses: challenges and rewards. International Dairy Journal, 14(5), 375-387. http://dx.doi. org/10.1016/j.idairyj.2003.08.008.

Brufau, G., Canela, M. A., \& Rafecas, M. (2008). Phytosterols: physiologic and metabolic aspects related to cholesterol-lowering properties. Nutrition Research (New York, N.Y.), 28(4), 217-225. http://dx.doi. org/10.1016/j.nutres.2008.02.003. PMid:19083411.

Capozzi, V., Russo, P., Dueñas, M. T., López, P., \& Spano, G. (2012). Lactic acid bacteria producing B-group vitamins: a great potential for functional cereals products. Applied Microbiology and Biotechnology, 96(6), 1383-1394. http://dx.doi.org/10.1007/s00253-012-4440-2. PMid:23093174.

Casarotti, S. N., Borgonovi, T. F., Batista, C. L. F. M., \& Penna, A. L. B. (2018). Guava, orange and passion fruit by-products: characterization and its impacts on kinetics of acidification and properties of probiotic fermented products. $L W T, 98,69-76$. http://dx.doi.org/10.1016/j. lwt.2018.08.010.

Chandan, R. C. (2007). Manufacturing yogurt and fermented milks. In N. P. Shah (Ed.), Manufacturing yogurt and fermented milks (pp. 1-364). USA: Elsevier. https://doi.org/10.1002/9780470277812.

Choudhary, A., Kumar, A., \& Kaur, N. (2019). ROS and oxidative burst: roots in plant development. Plant Diversity, 42(1), 33-43. http:// dx.doi.org/10.1016/j.pld.2019.10.002. PMid:32140635.

Coïsson, J. D., Travaglia, F., Piana, G., Capasso, M., \& Arlorio, M. (2005). Euterpe oleracea juice as a functional pigment for yogurt. Food Research International, 38(8-9), 893-897. http://dx.doi.org/10.1016/j. foodres.2005.03.009.

Csapó, J., \& Varga-Visi, E. (2015). Conjugated linoleic acid production in fermented foods. In W. Holzapfel (Ed.), Advances in fermented foods and beverages: improving quality, technologies and health benefits. USA: Elsevier Ltd. http://dx.doi.org/10.1016/B978-178242-015-6.00004-9.

Cutrim, C. S., \& Cortez, M. A. S. (2018). A review on polyphenols: classification, beneficial effects and their application in dairy products. International Journal of Dairy Technology, 71(3), 564-578. http://dx.doi.org/10.1111/1471-0307.12515.

da Costa, J. P. (2017). A current look at nutraceuticals - Key concepts and future prospects. Trends in Food Science \& Technology, 62, 6878. http://dx.doi.org/10.1016/j.tifs.2017.02.010.

de Campo, C., Queiroz Assis, R., Marques da Silva, M., Haas Costa, T. M., Paese, K., Stanisçuaski Guterres, S., de Oliveira Rios, A., \& Hickmann Flôres, S. (2019). Incorporation of zeaxanthin nanoparticles in yogurt: Influence on physicochemical properties, carotenoid stability and sensory analysis. Food Chemistry, 301, 125230. http://dx.doi. org/10.1016/j.foodchem.2019.125230. PMid:31374531. de Carvalho, M. W., Arriola, N. D. A., Pinto, S. S., Verruck, S., FritzenFreire, C. B., Prudêncio, E. S., \& Amboni, R. D. (2019). Steviafortified yoghurt: Stability, antioxidant activity and in vitro digestion behaviour. International Journal of Dairy Technology, 72(1), 57-64. http://dx.doi.org/10.1111/1471-0307.12559.

Demonty, I., Ras, R. T., van der Knaap, H. C. M., Duchateau, G. S. M. J. E., Meijer, L., Zock, P. L., Geleijnse, J. M., \& Trautwein, E. A. (2009). Continuous Dose-Response Relationship of the LDLCholesterol-Lowering Effect of Phytosterol Intake. The Journal of Nutrition, 139(2), 271-284. http://dx.doi.org/10.3945/jn.108.095125. PMid:19091798.

Dismore, M. L., Haytowitz, D. B., Gebhardt, S. E., Peterson, J. W., \& Booth, S. L. (2003). Vitamin K content of nuts and fruits in the US diet. Journal of the American Dietetic Association, 103(12), 1650-1652. http://dx.doi.org/10.1016/j.jada.2003.09.028. PMid:14647095.

Domínguez Díaz, L., Fernández-Ruiz, V., \& Cámara, M. (2020). An international regulatory review of food health-related claims in functional food products labeling. Journal of Functional Foods, 68, 103896. http://dx.doi.org/10.1016/j.jff.2020.103896.

El Hatmi, H., Jrad, Z., Oussaief, O., Nasri, W., Sbissi, I., Khorchani, T., \& Canabady-Rochelle, L. L. S. (2018). Fermentation of dromedary camel (Camelus dromedarius) milk by Enterococcus faecium, Streptococcus macedonicus as a potential alternative of fermented cow milk. LWT, 90, 373-380. http://dx.doi.org/10.1016/j.lwt.2017.12.040.

Espírito Santo, A. P., Silva, R. C., Soares, F. A. S. M., Anjos, D., Gioielli, L. A., \& Oliveira, M. N. (2010). Açai pulp addition improves fatty acid profile and probiotic viability in yoghurt. International Dairy Journal, 20(6), 415-422. http://dx.doi.org/10.1016/j.idairyj.2010.01.002.

Espírito-Santo, A. P., Lagazzo, A., Sousa, A. L. O. P., Perego, P., Converti, A., \& Oliveira, M. N. (2013). Rheology, spontaneous whey separation, microstructure and sensorial characteristics of probiotic yoghurts enriched with passion fruit fiber. Food Research International, 50(1), 224-231. http://dx.doi.org/10.1016/j.foodres.2012.09.012.

Everett, D. W., \& McLeod, R. E. (2005). Interactions of polysaccharide stabilisers with casein aggregates in stirred skim-milk yoghurt. International Dairy Journal, 15(11), 1175-1183. http://dx.doi. org/10.1016/j.idairyj.2004.12.004.

Fazilah, N. F., Ariff, A. B., Khayat, M. E., Rios-Solis, L., \& Halim, M. (2018). Influence of probiotics, prebiotics, synbiotics and bioactive phytochemicals on the formulation of functional yogurt. Journal of Functional Foods, 48, 387-399. http://dx.doi.org/10.1016/j. jff.2018.07.039.

Ferguson, J. J. A., Stojanovski, E., MacDonald-Wicks, L., \& Garg, M. L. (2016). Fat type in phytosterol products influence their cholesterollowering potential: A systematic review and meta-analysis of RCTs. Progress in Lipid Research, 64, 16-29. http://dx.doi.org/10.1016/j. plipres.2016.08.002. PMid:27497855.

Fidelis, M., de Oliveira, S. M., Sousa Santos, J., Bragueto Escher, G., Silva Rocha, R., Gomes Cruz, A., Araújo Vieira do Carmo, M., Azevedo, L., Kaneshima, T., Oh, W. Y., Shahidi, F., \& Granato, D. (2020). From byproduct to a functional ingredient: Camu-camu (Myrciaria dubia) seed extract as an antioxidant agent in a yogurt model. Journal of Dairy Science, 103(2), 1131-1140. http://dx.doi. org/10.3168/jds.2019-17173. PMid:31759605.

Fiorda, F. A., de Melo Pereira, G. V., Thomaz-Soccol, V., Rakshit, S. K., Pagnoncelli, M. G. B., Vandenberghe, L. P., \& Soccol, C. R. (2017). Microbiological, biochemical, and functional aspects of sugary kefir fermentation - A review. Food Microbiology, 66, 86-95. http://dx.doi. org/10.1016/j.fm.2017.04.004. PMid:28576377.

Fleshman, M. K., Lester, G. E., Riedl, K. M., Kopec, R. E., Narayanasamy, S., Curley, R. W., Jr., Schwartz, S. J., \& Harrison, E. H. (2011). Carotene 
and novel apocarotenoid concentrations in orange-fleshed cucumis melo melons: determinations of $\beta$-carotene bioaccessibility and bioavailability. Journal of Agricultural and Food Chemistry, 59(9), 4448-4454. http://dx.doi.org/10.1021/jf200416a. PMid:21417375.

Food and Agriculture Organization of the United Nations - FAO. (1995). Codex alimentarius commission. In Food and Agriculture Organization of the United Nations - FAO. Encyclopedia of food security and sustainability (pp. 50-55). Rome: FAO. https://doi. org/10.1016/B978-0-08-100596-5.22376-7.

Food and Agriculture Organization of the United Nations - FAO. (2003). Standard for fermented milks. Rome: FAO.

Gengatharan, A., Dykes, G. A., \& Choo, W. S. (2016). Stability of betacyanin from red pitahaya (Hylocereus polyrhizus) and its potential application as a natural colourant in milk. International Journal of Food Science \& Technology, 51(2), 427-434. http://dx.doi.org/10.1111/ijfs.12999.

Granato, D., Santos, J. S., Salem, R. D., Mortazavian, A. M., Rocha, R. S., \& Cruz, A. G. (2018). Effects of herbal extracts on quality traits of yogurts, cheeses, fermented milks, and ice creams: a technological perspective. Current Opinion in Food Science, 19, 1-7. http://dx.doi. org/10.1016/j.cofs.2017.11.013.

Gullon, B., Pintado, M. E., Pérez-Álvarez, J. A., \& Viuda-Martos, M. (2016). Assessment of polyphenolic profile and antibacterial activity of pomegranate peel (Punica granatum) flour obtained from coproduct of juice extraction. Food Control, 59, 94-98. http://dx.doi. org/10.1016/j.foodcont.2015.05.025.

Hill, C., Guarner, F., Reid, G., Gibson, G. R., Merenstein, D. J., Pot, B., Morelli, L., Canani, R. B., Flint, H. J., Salminen, S., Calder, P. C., \& Sanders, M. E. (2014). The International Scientific Association for Probiotics and Prebiotics consensus statement on the scope and appropriate use of the term probiotic. Nature Reviews Gastroenterology \& Hepatology, 11(8), 506-514. https:// doi.org/10.1038/nrgastro.2014.66.

Jaimez-Ordaz, J., Martínez-Ramírez, X., Cruz-Guerrero, A. E., ContrerasLópez, E., Ayala-Niño, A., Castro-Rosas, J., \& González-Olivares, L. G. (2019). Survival and proteolytic capacity of probiotics in a fermented milk enriched with agave juice and stored in refrigeration. Food Science and Technology (Campinas), 39(1), 188-194. http:// dx.doi.org/10.1590/fst.41117.

Karnopp, A. R., Oliveira, K. G., de Andrade, E. F., Postingher, B. M., \& Granato, D. (2017). Optimization of an organic yogurt based on sensorial, nutritional, and functional perspectives. Food Chemistry, 233, 401-411. http://dx.doi.org/10.1016/j.foodchem.2017.04.112. PMid:28530591.

Lee, C. S., Lee, S. H., \& Kim, S. H. (2020). Bone-protective effects of Lactobacillus plantarum B719-fermented milk product. International Journal of Dairy Technology, 73(4), 706-717. http:// dx.doi.org/10.1111/1471-0307.12701.

Li, A.-N., Li, S., Zhang, Y.-J., Xu, X.-R., Chen, Y.-M., \& Li, H.-B. (2014). Resources and Biological Activities of Natural Polyphenols. Nutrients, 6(12), 6020-6047. http://dx.doi.org/10.3390/nu6126020. PMid:25533011.

Maiani, G., Castón, M. J., Catasta, G., Toti, E., Cambrodón, I. G., Bysted, A., Granado-Lorencio, F., Olmedilla-Alonso, B., Knuthsen, P., Valoti, M., Böhm, V., Mayer-Miebach, E., Behsnilian, D., \& Schlemmer, U. (2009). Carotenoids: actual knowledge on food sources, intakes, stability and bioavailability and their protective role in humans. Molecular Nutrition \& Food Research, 53(Suppl 2), S194-S218. http:// dx.doi.org/10.1002/mnfr.200800053. PMid:19035552.

Medeiros, A. K., Gomes, C. C., Amaral, M. L. Q. A., Medeiros, L. D. G., Medeiros, I., Porto, D. L., Aragão, C. F. S., Maciel, B. L. L., Morais, A. H. A., \& Passos, T. S. (2019). Nanoencapsulation improved water solubility and color stability of carotenoids extracted from
Cantaloupe melon (Cucumis melo L.). Food Chemistry, 270, 562-572. http://dx.doi.org/10.1016/j.foodchem.2018.07.099. PMid:30174087.

Mellidou, I., Georgiadou, E. C., Kaloudas, D., Kalaitzis, P., Fotopoulos, V., \& Kanellis, A. K. (2019). Vitamins. In E. M. Yahia (Ed.), Postharvest physiology and biochemistry of fruits and vegetables (pp. 359-383). USA: Elsevier. http://dx.doi.org/10.1016/B978-0-12-813278-4.00017-8.

Miao, W., He, R., Feng, L., Ma, K., Zhang, C., Zhou, J., Chen, X., Rui, X., Zhang, Q., Dong, M., Li, W., \& Xu, Q. (2020). Study on processing stability and fermentation characteristics of donkey milk. LWT, 124, 109151. http://dx.doi.org/10.1016/j.lwt.2020.109151.

Nawirska, A., \& Kwaśniewska, M. (2005). Dietary fibre fractions from fruit and vegetable processing waste. Food Chemistry, 91(2), 221-225. http://dx.doi.org/10.1016/j.foodchem.2003.10.005.

Pantelić, M. M., Dabić Zagorac, D. Č., Davidović, S. M., Todić, S. R., Bešlić, Z. S., Gašić, U. M., Tešić, Ž. L., \& Natić, M. M. (2016). Identification and quantification of phenolic compounds in berry skin, pulp, and seeds in 13 grapevine varieties grown in Serbia. Food Chemistry, 211, 243-252. http://dx.doi.org/10.1016/j.foodchem.2016.05.051. PMid:27283628.

Pena, F. L., Souza, M. C., Valle, M. C. P. R., Bezerra, R. M. N., Rostagno, M. A., \& Antunes, A. E. C. (2021). Probiotic fermented milk with high content of polyphenols: study of viability and bioaccessibility after simulated digestion. International Journal of Dairy Technology, 74(1), 170-180. http://dx.doi.org/10.1111/1471-0307.12735.

Pimentel, T. C., Antunes, A. E. C., Zacarchenco, P. B., Cortez, M. A. S., Bogsan, C. S. B., Oliveira, M. N., Esmerino, E. A., Silva, M. C., \& Cruz, A. G. (2017). Brazilian Yogurt-like products. In N.P. Shah (Ed.), Yogurt in health and desease prevention (chap. 19, pp. 331-350). London: Elsevier. http://dx.doi.org/10.1016/B978-0-12805134-4.00019-5.

Pranav, K. S., \& Nagendra, P. S. (2017). Other fermented dairy products: Kefir and Koumiss. In N.P. Shah (Ed.), Yogurt in health and desease prevention (chap. 5, pp. 87-106). London: Elsevier.

Ranadheera, C. S., Naumovski, N., \& Ajlouni, S. (2018). Non-bovine milk products as emerging probiotic carriers: recent developments and innovations. Current Opinion in Food Science, 22, 109-114. http://dx.doi.org/10.1016/j.cofs.2018.02.010.

Rasika, D. M. D., Munasinghe, M. A. D. D., Vidanarachchi, J. K., da Cruz, A. G., Ajlouni, S., \& Ranadheera, C. S. (2020). Probiotics and prebiotics in non-bovine milk (pp. 339-384). https://doi.org/10.1016/ bs.afnr.2020.06.008.

Rodriguez-Amaya, D. B., \& Kimura, M. (2004). HarvestPlus handbook for carotenoid analysis (Vol. 2, HarvestPlus Technical Monograph Series). Washington: HarvestPlus.

Rodriguez-Concepcion, M., Avalos, J., Bonet, M. L., Boronat, A., Gomez-Gomez, L., Hornero-Mendez, D., Limon, M. C., MeléndezMartínez, A. J., Olmedilla-Alonso, B., Palou, A., Ribot, J., Rodrigo, M. J., Zacarias, L., \& Zhu, C. (2018). A global perspective on carotenoids: metabolism, biotechnology, and benefits for nutrition and health. Progress in Lipid Research, 70, 62-93. http://dx.doi.org/10.1016/j. plipres.2018.04.004. PMid:29679619.

Salo, P., \& Kuusisto, P. (2016). Cholesterol lowering effect of plant stanol ester yoghurt drinks with added camelina oil. Cholesterol, 2016, 1-12. http://dx.doi.org/10.1155/2016/5349389. PMid:26998355.

Sembries, S., Dongowski, G., Jacobasch, G., Mehrländer, K., Will, F., \& Dietrich, H. (2003). Effects of dietary fibre-rich juice colloids from apple pomace extraction juices on intestinal fermentation products and microbiota in rats. The British Journal of Nutrition, 90(3), 607-615. http://dx.doi.org/10.1079/ BJN2003925. PMid:13129467. 
Septembre-Malaterre, A., Remize, F., \& Poucheret, P. (2018). Fruits and vegetables, as a source of nutritional compounds and phytochemicals: changes in bioactive compounds during lactic fermentation. Food Research International, 104, 86-99. http://dx.doi.org/10.1016/j. foodres.2017.09.031. PMid:29433787.

Serra, J. L., Rodrigues, A. M. D. C., de Freitas, R. A., Meirelles, A. J. A., Darnet, S. H., \& Silva, L. H. M. D. (2019). Alternative sources of oils and fats from Amazonian plants: fatty acids, methyl tocols, total carotenoids and chemical composition. Food Research International, 116, 12-19. http://dx.doi.org/10.1016/j.foodres.2018.12.028. PMid:30716906.

Shafi, A., Naeem Raja, H., Farooq, U., Akram, K., Hayat, Z., Naz, A., \& Nadeem, H. R. (2019). Antimicrobial and antidiabetic potential of synbiotic fermented milk: a functional dairy product. International Journal of Dairy Technology, 72(1), 15-22. http://dx.doi. org/10.1111/1471-0307.12555.

Silva-Rodrigues, H. C., Silveira, M. P., Helm, C. V., Matos Jorge, L. M., \& Jorge, R. M. M. (2020). Gluten free edible film based on rice flour reinforced by guabiroba (Campomanesia xanthocarpa) pulp. Journal of Applied Polymer Science, 49254(41), 49254. http://dx.doi. org/10.1002/app.49254.

Soto, R. I., Jiménez-Munguía, M. T., Mani-López, E., Palou, E., \& LópezMalo, A. (2019). Growth and viability of Lactobacillus acidophilus NRRL B-4495, Lactobacillus casei NRRL B-1922 and Lactobacillus plantarum NRRL B-4496 in milk supplemented with cysteine, ascorbic acid and tocopherols. International Dairy Journal, 97, 1524. http://dx.doi.org/10.1016/j.idairyj.2019.05.003.

Surono, I. S., \& Hosono, A. (2011). Fermented milks: types and standards of identity. In J. W. Fuqway \& P. F. Fox (Eds.), Encyclopedia of dairy sciences (2nd ed., pp. 470-476). London: Elsevier Inc. http://dx.doi. org/10.1016/B978-0-12-374407-4.00180-1

Verruck, S., Barretta, C., Miotto, M., Canella, M. H. M., de Liz, G. R., Maran, B. M., Garcia, S. G., da Silveira, S. M., Vieira, C. R. W., da Cruz, A. G., \& Prudencio, E. S. (2020). Evaluation of the interaction between microencapsulated Bifidobacterium BB-12 added in goat's milk Frozen Yogurt and Escherichia coli in the large intestine. Food Research International, 127, 108690. http://dx.doi.org/10.1016/j. foodres.2019.108690. PMid:31882106.
Verruck, S., Dantas, A., \& Prudencio, E. S. (2019). Functionality of the components from goat's milk, recent advances for functional dairy products development and its implications on human health. Journal of Functional Foods, 52, 243-257. http://dx.doi.org/10.1016/j.jff.2018.11.017.

Vicenssuto, G. M., \& de Castro, R. J. S. (2020). Development of a novel probiotic milk product with enhanced antioxidant properties using mango peel as a fermentation substrate. Biocatalysis and Agricultural Biotechnology, 24, 101564. http://dx.doi.org/10.1016/j. bcab.2020.101564.

Wang, X., Kristo, E., \& LaPointe, G. (2020). Adding apple pomace as a functional ingredient in stirred-type yogurt and yogurt drinks. Food Hydrocolloids, 100, 105453. http://dx.doi.org/10.1016/j. foodhyd.2019.105453.

Yahia, E. M., García-Solís, P., \& Celis, M. E. M. (2019). Contribution of fruits and vegetables to human nutrition and health. In E. M. Yahia (Ed.), Postharvest physiology and biochemistry of fruits and vegetables (pp. 19-45). USA: Elsevier. http://dx.doi.org/10.1016/ B978-0-12-813278-4.00002-6.

Yassin, L. S., Alberti, A., Ferreira Zielinski, A. A., da Rosa OliveiraEmilio, H., \& Nogueira, A. (2018). Cytoprotective effect of phenolic extract from Brazilian apple peel in insulin-producing cells. Current Nutrition and Food Science, 14(2), 136-142. http://dx.doi.org/10.21 74/1573401313666170427125753.

Zheng, J., Wittouck, S., Salvetti, E., Franz, C. M. A. P., Harris, H. M. B., Mattarelli, P., O’Toole, P. W., Pot, B., Vandamme, P., Walter, J., Watanabe, K., Wuyts, S., Felis, G. E., Gänzle, M. G., \& Lebeer, S. (2020). A taxonomic note on the genus Lactobacillus: description of 23 novel genera, emended description of the genus Lactobacillus Beijerinck 1901, and union of Lactobacillaceae and Leuconostocaceae. International Journal of Systematic and Evolutionary Microbiology, 70(4), 2782-2858. http://dx.doi.org/10.1099/ijsem.0.004107. PMid:32293557.

Zielinski, A. A., Zardo, D. M., Alberti, A., Bortolini, D. G., Benvenutti, L., Demiate, I. M., \& Nogueira, A. (2019). Effect of cryoconcentration process on phenolic compounds and antioxidant activity in apple juice. Journal of the Science of Food and Agriculture, 99(6), 2786-2792. http://dx.doi.org/10.1002/jsfa.9486. PMid:30430576. 